\title{
JOB PLACEMENT OF THE BACHELOR OF SCIENCE IN AGRICULTURE (BSA) GRADUATES OF LEYTE STATE UNIVERSITY 1 !
}

\author{
Daisy S. Capon \\ Instructor, Foundation University \\ Dumaguete City \\ and \\ Antonia Cecilia Y. Sandoval \\ Professor, College of Education : \\ Leyte State University, Visca, Baybay, Leyte
}

\begin{abstract}
This study determined the job placement of BSA graduates of Leyte State University from SY 1994 -1995 to 1996 - 2000. Results. showed that more than half of the graduates were employed either in government or in private sector with $50 \%$ having a contractual appointment and three-fourths landing in jobs related to agriculture. Majority of the respondents were non-eligibles although, they considered the skills and knowledge acquired in college as relevant to their present job. Their sociodemographic characteristics, including eligibility, were not significantly related to employment status.
\end{abstract}

KEY WORD: Job placement. BSA graduates.

11 Part of MS thesis of the senior author 


\section{INTRODUCTION}

The proliferation of agricultural baccalaureate degrees in the Philippines has led to an oversupply of professionals in agriculture (Dumlao, as cited by Villaseñor, 1993). Because of this, a number of graduates of agriculture find difficulty in getting jobs commensurate to their educational qualifications. Moreover, despite the oversupply of agriculture graduates in the country, the government has been very slow in responding to the problem of high unemployment rates of educated manpower. Thus, this study aimed to find out the job placement of BSA graduates of Leyte State University.

\section{Conceptual Framework}

The variables of the study included socio-demographic characteristics of the respondents such as age, sex, civil status, educational attainment, field of specialization and eligibility as they relate to job placement of the graduates (Figure 1).

Independent Variable

Socio-demographic

Characteristics of

BSA Graduates

Age

$>$ Sex

$>$ Civil status

$>$ Major Field of Specialization

$>$ Eligibility

$>$ Educational Attainment
Dependent Variable

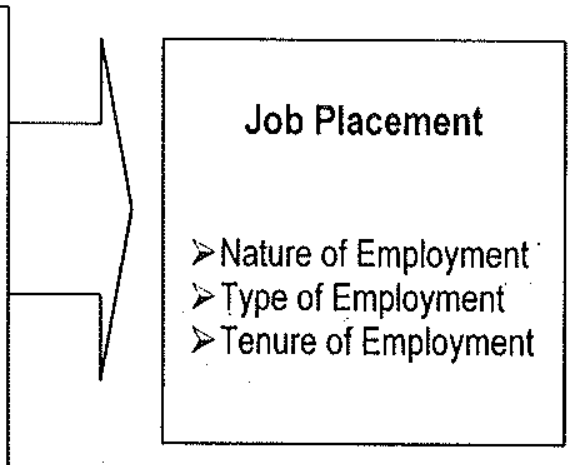

Figure 1. Conceptual diagram showing the relationship of variables. 


\section{METHODOLOGY}

Three hundred seventy-four (374) Bachelor of Science in Agriculture (BSA) graduates of the Leyte State University (LSU) were recorded from school year 1994-1995 to SY 1999-2000. Of this number, one hundred fifty (150) were randomly chosen as respondents for this study.

\section{Sampling Procedure}

Random sampling technique was done using the names and addresses of all BSA graduates in each school year. A self-administered structured questionnaire was used in gathering data for this study. It was divided into four parts: Part I - Socio-demographic characteristics, Part II Job placement of the respondents, Part III - Curriculum-related factors associated with job placement and Part IV-Other factors associated with job placement.

\section{Data Collection and Analysis}

Questionnaires were personally administered by the researcher for those graduates residing in or working within Baybay. For graduates working far from LSU, questionnaires were sent by mail with selfaddressed and stamped envelopes to make sure that they would be returned to the researcher. A series of follow-up were also done to ensure prompt responses.

The data were analyzed using frequency counts, percentages and means. To determine the relationships between selected variables to employment status, the Chi-square test was used. The five-percent probability level was used to determine the significance of relationships between variables. 


\section{RESULTS AND DISCUSSION}

Results showed that majority of employed respondents were young female and single. The reason for this could be the fact that young and single graduates are presumed to perform better especially in jobs requiring manipulative skills. The employed graduates were willing to travel, work overtime or be assigned in remote areas. Dobrish (1984) reported that young graduates had more self-confidence and self-esteem and open to new ideas and opinions. Of the 150 total respondents, only 104 of the respondents were gainfully employed.

Out of the 104 employed respondents, $84.46 \%$ worked on full-time basis, while the others were employed on a part-time or contractual scheme. A little over three-fourths landed in jobs which were agriculturerelated, while $21.15 \%$ had jobs which were not related to agriculture.

The agriculture-related positions occupied by the respondents include Science Research Assistant, Instructor, Agricultural Technician, Agronomist, Horticulturist, Pest Control Specialist and Community Organizer. Half of the respondents were having contractual, casual or temporary appointment in government offices, while the rest were in private sectors. IBON (2002) reported that in the Philippines, no fundamental progress had occurred in the field of agriculture for the country to create more jobs and increase productivity. The entry of the Philippines in the World Trade Organization had resulted in fewer jobs in agriculture since 1996. Hundreds of thousands of jobs were lost in agriculture for the period $1999-2000$.

It could be noted that employment opportunities were adversely affected by the economic crisis the country was experiencing during the time when the study was conducted. As an effect, some graduates were forced to accept jobs which were not related to their educational preparation. 


\section{Distribution of Employed Respondents and their Eligibility}

Among those BSA graduates with certificates of eligibility, 33 or $31.73 \%$ worked in the government; 10 or $9.62 \%$ were employed in private firms, and only one was self-employed. On the other hand, those without eligibility certificates, 25 or $26 \%$ were employed in the government, 29 or about $28 \%$ worked in private companies, and 6 or $6 \%$ were self-employed. This study confirmed the findings of Mancebo (1992) which revealed that civil service eligibility was not normally required in state colleges and universities and in private institutions as long as the graduates' field of expertise fitted the particular work assignment.

Table 1. Distribution of employed respondents and their eligibility.

Employed Respondents

Frequency
$(n=104)$

Eligible

Government

Private

Self-employed

Non-eligible

Government

Private

Self-empioyed
33

10

1

Subtotal

Percentage

(\%)

\begin{tabular}{lcc} 
& 33 & 31.73 \\
& 10 & 9.62 \\
& 1 & 0.96 \\
Subtotal & $-\ldots .--$ \\
& 44 & 42.31 \\
& 25 & \\
& 29 & 24.04 \\
& 6 & 27.88 \\
Subtotal & $-\ldots 0$ & 5.77 \\
Total & 104 & 57.69 \\
\hline
\end{tabular}

\section{Factors that Influence Job Placement}

Job placement was influenced by a number of factors, suggesting that graduates should equip themselves with the necessary qualifications in order to have an edge over the other applicants (Table 2). 
Nine factors related to job placement influenced the success of job seekers, namely: communication skills, examination performance, opportunity, relevance of the major fields of the applicant, managerial skill, academic performance, persistence, manipulative skills, and pleasing personality. Only two items had very little influence and these were letter of recommendation and political connection.

Political connection, although the last-ranking factor associated with job placement, was one sad reality every graduate should have to accept. Some respondents reported that most agencies or institutions had intensive recruitment and selection procedures in hiring employees, but some also had the same procedure for formality's sake only. For instance, even if the applicant does not possess the necessary qualifications, but if he has strong political backup, he will be hired. In the worst scenario, a person who is not even in the list of applicants is the one being employed. Thus, some graduates felt demoralized and frustrated resulting in their loss of interest in job seeking.

Table 2. Factors that influence job placement as perceived by respondents.

\begin{tabular}{|c|c|c|c|}
\hline Factors & $\begin{array}{l}\text { Weighted } \\
\text { Mean Score } 1\end{array}$ & Interpretation & Rank \\
\hline Communication skills & 1.817 & much influence & 1 \\
\hline $\begin{array}{l}\text { Performance in examinations and } \\
\text { interview given by agency personnel }\end{array}$ & 1856 & much influence & 2 \\
\hline Opportunity & 1.884 & much influence & 3 \\
\hline $\begin{array}{l}\text { Relevance of the major field of } \\
\text { specialization }\end{array}$ & 1.913 & much influence & 4 \\
\hline Managerial śkill & 2.057 & much influence & 5 \\
\hline Academic performance & 2,096 & much influence & 6 \\
\hline Persistence in job seeking & 2.202 & much influence & 7 \\
\hline Manipulative skill & 2.057 & much influence & 8 \\
\hline Pleasing personality & 2.075 & much influence & 9 \\
\hline Favorable letter of recommendation. & 3.769 & very little influence & 10 \\
\hline Political connection & 4.000 & very little influence & 11 \\
\hline $\begin{array}{l}11 \text { Scale Used: } \\
1 \text { - very much influence } \\
2 \text { - much influence } \\
3 \text { - little influence }\end{array}$ & & $\begin{array}{l}\text { little influence } \\
\text { at all }\end{array}$ & \\
\hline
\end{tabular}




\section{Curriculum-Related Factors}

About $57 \%$ revealed that their acquired degree program was "very relevant"; $21 \%$ "relevant" and still another $22 \%$ "not relevant" to their present works (Table 3). The respondents, however, believed that the knowledge and skills they acquired from the existing BSA curriculum had been very useful to their job performance.

Table 3. Degree of relevance of curriculum to present job.

\begin{tabular}{lcc}
\hline \hline Degree of Relevance & $\begin{array}{c}\text { Frequency } \\
(\mathrm{n}=104)\end{array}$ & $\begin{array}{c}\text { Percentage } \\
(\%)\end{array}$ \\
\hline Very relevant & & \\
Relevant & 59 & 56.73 \\
Not relevant & 22 & 21.15 \\
& 23 & 22.11 \\
\hline Total & & \\
\hline
\end{tabular}

Under crop production technology (Table 4), field crop production (2.17) was the most relevant, followed by integrated pest management (2.12). These areas were usually useful to the respondents who were farm managers, agricultural technicians, community organizers and instructors of agricultural state colleges and universities.

Postharvest technology, specifically the basic principles in postharvest technology and processing horticultural and animal products, was considered relevant $(2.00)$ by the respondents. On the other hand, under the management aspect, agricultural marketing, agricultural business finance and farm business management were considered relevant to their present job. 
Table 4. Relevance of subject matter areas to present job.

\begin{tabular}{|c|c|c|c|}
\hline Degree of Relevance & $\begin{array}{c}\text { Weighted } \\
\text { Mean Score }\end{array}$ & $\begin{array}{l}\text { Degree of } \\
\text { Relevance }\end{array}$ & Rank \\
\hline \multicolumn{4}{|l|}{ Crop Production Technology } \\
\hline Field Crop Production & 2.17 & relevant & 1 \\
\hline Integrated Pest Management & 2.12 & relevant & 2 \\
\hline Farming System & 2.11 & relevant & 3 \\
\hline Horticultural Crop Production & 2.10 & relevant & 4 \\
\hline \multicolumn{4}{|l|}{ Plant Propagation and Nursery } \\
\hline Management & 1.99 & relevant & 5 \\
\hline Soil Management and Conservation & 1.94 & relevant & 6 \\
\hline \multicolumn{4}{|l|}{ Post Harvest Technology } \\
\hline \multicolumn{4}{|l|}{ Basic Principles in Post Havest } \\
\hline Technology & 2.00 & relevant & 1 \\
\hline Processing Horticultural Products & 1.78 & relevant & 2 \\
\hline Processing of Animal Products & 1.50 & relevant & 3 \\
\hline \multicolumn{4}{|l|}{ Management } \\
\hline Agricultural Marketing & 1.80 & relevant & 1 \\
\hline Agricultural and Business Finance & 1.71 & relevant & 2 \\
\hline Farm Business Management & 1.70 & relevant & 3 \\
\hline
\end{tabular}

\section{Socio-Demographic Characteristics and Job Placement}

Age, sex, civil status and eligibility were not significantly related to the nature of employment, whether the respondents worked on a full-time or part-time basis. This means that BSA graduates had equal chances of getting full-time or part-time jobs regardless of ages, sex, marital status or 
eligibility. However, major field of specialization and educational attainment were significantly related to nature of employment (Table 5). This is evident because their major field of specialization was an important consideration in the hiring of part-time and full-time applicants.

Table 5. Socio-demographic characteristics of respondents and nature of employment.

\begin{tabular}{lcc}
\hline \hline Socio-Demographic Characteristics & Nature of Employment & Chi-square \\
& $\begin{array}{c}\text { Value } \\
\text { Full-Time }\end{array}$ & Part-time \\
\hline
\end{tabular}

Age

Young

Middle-Age

$48 \therefore 7$
36 $\quad \therefore \quad 6$

0.050

Sex

Female

Male

54

8

30

5

0.037

\section{Civil Status}

Single

Married

71

13

12

0

0.205

Major Field of Specialization

Crop Science

Non-Crop Science

82

10

23

$9.863^{*}$

Eligibility

Eligible

Non-eligible

34

7

50

6

0.825

\section{Edy cational Attainment}

Bachelor's Degree

65

Advanced Degree

19

${ }^{*} p<.05 ; \quad{ }^{\star *} p<.01$ 
Age, sex and major field of specialization were not significantly related to types of employment such as primary, secondary or tertiary employment (Table 6). On the other hand, civil status, eligibility and educational attainment were significantly related to types of employment.

Table 6. Socio-demographic characteristics of respondents and type of employment.

\begin{tabular}{lccccc}
\hline \hline Socio-Demographic Characteristics & Type of Employment & $\begin{array}{c}\text { Chi-square } \\
\text { Value }\end{array}$ \\
& Primary & Secondary & Tertiary & \\
\hline Age & 41 & 3 & & 11 & \\
$\quad$ Young & 25 & 2 & 15 & 3.006 \\
$\quad$ Middle-Age & 25 & & & &
\end{tabular}

Sex

$\begin{array}{lrrrr}\text { Fermale } & 42 & 3 & 17 & \\ \text { Male } & 24 & 2 & 9 & 0.060\end{array}$

Civil Status

Single

Married

Major Field of Specialization

Crop Science

Non-Crop Science

\section{Eligibility}

Eligible

Non-Eligible

\section{Educational Attainment}

\begin{tabular}{lllll} 
Bachelor's Degree & 37 & 5 & 20 & \\
Advanced Degree & 29 & - & - & $10.162^{* *}$ \\
\hline \hline$p<.05 ; \quad{ }^{* k} p<.0 .1$ &
\end{tabular}


Results showed that single graduates were preferred to married applicants regardless of type of employment. Recasa (1998) supported the finding of Storeffer (1962) that married persons sometimes became less efficient because of family matters: They easily become tensed, anxious and frustrated. Thumchob (1976) confirmed this in his study that workers who had families to take care of either neglected their work or had poor concentration on the job.

The educational attainment was highly related to type of employment. Results showed that in all three types of employment, baccalaureate degree holders predominated. For primary employment, graduates having advanced degrees were preferred. According to Ungerson (1975), the employers presumed that postgraduate applicants were more knowledgeable, had more self-confidence and self-esteem, and would perform better on the job.

\section{Socio-Demographic Characterisitics and}

\section{Tenure of Employment}

Sex and educational attainment were significantly related to tenure (Table 7). Most of the employed respondents having permanent positions were females. This could be attributed to the observation that women were generally more patient and persevering than men. Males, however, being the main providers of the family were more likely to seek better opportunities even if it meant being away from their families. Others, especially singles were more adventurous, ambitious and had high expectations and would not easily become tensed and frustrated because of the various roles they played as husband, parent and the like. Reciasa (1998) explained that such factors had adverse effects on their. job performance, thus, some employers would not choose them to fill up permanent positions.

Employed graduates occupying permanent and casual positions were mostly bachelor's degree holders. People who had attained higher levels of education were mostly contractuals since they tend to move from 
one job to another because of higher salary, career advancement and other better job opportunities. According to Ungerson (1975), personal conflicts in the workplace and bad choice of job or overwork forced them to change jobs.

\section{Strengths and Weaknesses of LSU BSA Curriculum}

Among the LSU BSA graduates, being knowledgeable, practical, output oriented and technically competent were the strongest points of the BSA curriculum. Wide employment opportunity for BSA graduates and the curriculum that promoted entrepreneurship were additional strengths of the BSA curriculum.

Table 7. Socio-demographic characteristics of respondents and tenure of employment.

\begin{tabular}{|c|c|c|c|c|}
\hline \multirow{2}{*}{ Socio-Demographic Characteristics } & \multicolumn{3}{|c|}{ Tenure of Employment } & \multirow{2}{*}{$\begin{array}{c}\text { Chi-square } \\
\text { Value }\end{array}$} \\
\hline & Primary & Secondary & Tertiary & \\
\hline \multicolumn{5}{|l|}{ Age } \\
\hline Young & 8 & 16 & 31 & \\
\hline Middle-Age & 14 & 12 & 16 & 5.349 \\
\hline \multicolumn{5}{|l|}{ Sex } \\
\hline Female & 16 & 12 & 34 & \\
\hline Male & 6 & 16 & 13 & $7.571^{\star}$ \\
\hline \multicolumn{5}{|l|}{ Civil Status } \\
\hline Single & 16 & 25 & 43 & \\
\hline Married & 6 & 3 & 4 & 4.790 \\
\hline \multicolumn{5}{|l|}{ Major Field of Specialization } \\
\hline Crop Science & 21 & 27 & 44 & \\
\hline Non-Crop Science & 1 & 1 & 27 & 0.305 \\
\hline \multicolumn{5}{|l|}{ Eligibility } \\
\hline Eligible & 12 & 9 & 23 & \\
\hline Non-Eligible & 10 & 19 & 27 & 2.537 \\
\hline \multicolumn{5}{|l|}{ Educational Attainment } \\
\hline Bachelor's Degree & 18 & 26 & 24 & \\
\hline Advanced Degree & 4 & 2 & 23 & $16.486^{\star \star}$ \\
\hline
\end{tabular}


The non-inclusion of computer subjects in the curriculum was found to be the weakest point of the program. The respondents believed that for LSU's BSA program to be more competitive in the workplace, it should include some training in basic computer science.

Another weak point of the BSA curriculum was the lack of field practice or on-the-job training/exposure in some major fields in the present BSA curriculum. The experience one got in conducting a thesis differed from field practice. Field practice was very important especially if the graduate landed in an extension job or became farm manager or farm operator.

Table 8. Strong and weak points of the BSA curriculum at LSU*.

Characteristics Frequency Rank

\section{Strengths}

Graduates are knowledgeable, practical,

out-put oriented and technically competent

Wide employment opportunities

Promotes entrepreneurship

Varied fields of specialization to choose from

Qualified and competent faculty

$\begin{array}{cc}123 & 1 \\ 36 & 2 \\ 27 & 3 \\ 24 & 4 \\ 13 & 5\end{array}$

\section{Weaknesses}

Non-inclusion of computer subjects in the curriculum

No field practice or on-the-job-training

Many unrelated or unnecessary subjects

Curricular program needs revision to meet

present demands

Very broad curriculum 


\section{Suggestions for the Improvement of the Curriculum}

Inclusion of basic computer subjects in the program and reviewing regularly and revising the present curriculum that provided updated information, technologies and innovations in agriculture and livelihood were some of the suggestions for improving the BSA curriculum. According to Sangalang (2000); people in the academe must review and revise the curricular offerings and re-define them in order to be relevant and responsive to the needs and demands of all sectors. The lack of insiructional accountability and the corresponding sanctions against nonperformers were the major reasons why schools of agriculture continued to perform below standard.

\section{IMPLICATIONS AND RECOMMENDATIONS}

\section{Implications}

1. BSA graduates were predominantly females. This showed that the field of agriculture was not solely a man's world

2. Eligibility of BSA graduates was generally not a deterrent factor to their employment. This implied that reputation, honor and prestige. of LSU provided a big contribution to the marketability of its graduates.

3. Most of the graduates considered the knowledge and skills acquired in college to be very relevant to their present job. This meant that generally the existing BSA curriculum was in good shape and sufficient to prepare the student for a future employment in agriculture.

4. Majority of the graduates got job in less than a year after graduation. BSA graduates should not fear ending jobless if they took their degree in LSU. 


\section{Recommendations}

1. As suggested by the respondents, the BSA program to be more relevant and competitive, should be updated, enriched and reviewed regularly. Field practice or exposure to entrepreneurship should be considered as a requirement for graduation in all major fields of specialization.

2. A study with employers of BSA graduates as respondents shourd also be conducted to determine the employability and the quality of performance of the graduates as well as the relevance of the present curriculum to the current needs of future employees.

3. A study to delve deeper into the problem of political interference as a factor for employment should be conducted to compare it using the educational qualifications of an applicant as a determining factor in one's employability.

\section{LITERATURE CITED}

DOBRISH, C. 1984. Hiring the right person for the right job. .Franklin Watts, New York. 332 pp.

IBON FACTS AND FIGURES. 2002. Causes of poverty. 25 (4) 4-5.

RECASA, M.Q. 1998. Job placement and employment status of trainees of the Foundation for Youth Development of the Philippines (FYDP) in Aklan province. Unpublished M.S. thesis. Visayas State College of Agriculture, Baybay, Leyte. 103pp.

SANGALANG, R. S and A.G. PAPA. 2000. Status of agricultural education in the Philippines. MARID Agribusiness Digest. 11 (2) 9-12. 
UNGERSON, B. 1975. Grower Press Recruitment Handbook, (2nd ed.). Grower Press, Great Britain. 332 pp.

VILLASEÑOR, P.L. 1988. Survival ability of under-employed, selfemployed and unemployed B.S. Agriculture graduates in Central Luzon State University. Medium. 10 (3-4) 11-13 \& 23-24

\section{ABOUT THE AUTHOR}

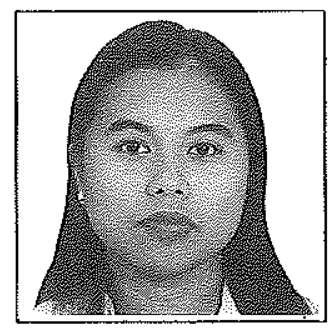

The author finished her Bachelor of Science in Agriculture major in Agricultural Botany in 1996. After graduation, she was hired as Science Research Assistant of the ViSCA-GTZ (Tropical Ecology Program) project entitled "Taxonomic Inventory of Vascular Plants in Mt. Pangasugan". She finished her Master of Science major in Agricultural Education from the Leyte State University (LSU) in March 2003.

She is now connected with the Foundation University in Dumaguete City as Instructor.

The co-author is a professor of the College of Education, Leyte State University, Visca, Baybay, Leyte. 